\title{
On The Limits of Judicial Intervention: EU Citizenship and Family Reunification Rights
}

\author{
Peter Van Elsuwege ${ }^{\text {a) }}$ and Dimitry Kochenov ${ }^{\text {) }}$ \\ a) Professor in EU Law, Ghent University Law School, Ghent, Belgium \\ b) Chair in EU Constitutional Law, Faculty of Law, University of Groningen, \\ Groningen, The Netherlands
}

\begin{abstract}
This article scrutinises the logic behind the recent judgments of the Court of Justice of the European Union (CJEU) in Ruiz Zambrano and McCarthy focusing on their implications for the right to family reunification under EU law. Specific attention is devoted to the phenomenon of reverse discrimination in the context of the new jurisdiction test established by the Court, which is based on the severity of the Member States' interference with EU citizenship rights rather than on a pure cross-border logic. EU citizens unable to establish a link with EU law are often subject to stricter family reunification requirements in comparison to their migrant compatriots and even certain third country nationals. It is argued that this situation is difficult to accept in light of the principles of legal certainty, equality and the protection of fundamental rights. A new balance between EU citizenship and Member States' regulatory autonomy is established but legislative action is required to solve the outstanding problems.
\end{abstract}

\section{Keywords}

EU citizenship; family reunification; third country nationals; purely internal rule; reverse discrimination

\section{Introduction}

The right to family reunification is an essential part of EU law. From the early days onwards, it has been recognised that the granting of rights to third country family members of a migrant Member State national is of crucial importance to ensure the effet utile of the freedom of movement for persons. ${ }^{1}$ The introduction of EU citizenship with the Treaty of Maastricht extended the scope of application of family reunification rights to Member State nationals that are not involved in economic activities. However, the Court of Justice of the European Union (CJEU) immediately asserted that EU citizenship is not intended to extend the scope rationae materiae of the Treaty also to internal situations which have no link with Community [now Union] law'. In other words, EU citizens can only rely on

1) Groenendijk, K., 'Family Reunification as a Right under Community Law', 2006 EJML 8(2), pp. 215230.

2) Joint cases C-64/96 and C-65/96, Kari Uecker and Vera Jacquet v. Land Nordrhein Westfalen [1997] ECR I-3171, para. 23. 
their EU citizenship rights, including a right of residence for their third country family members, when they fall within the scope of application of EU law. If their situation has no link with EU law, they are subject to the often more restrictive national rules of the Member States. This leads to the well-known phenomenon of reverse discrimination. ${ }^{3}$

The potential for reverse discrimination entirely depends on the dividing line between the scopes of EU and national law. This line is virtually never straightforward, to which the recent Court judgments in Ruiz Zambrano and McCarthy provide excellent illustrations. In both cases, the CJEU was confronted with the question whether third country nationals can derive a right of residence from their family relationship with an EU citizen who has never exercised free movement rights.

Making a swift move away from the traditionalist cross-border situation logic, ${ }^{4}$ in Ruiz Zambrano, the Grand Chamber of the Court accepted that the Colombian father of 'static' Belgian children had a right to reside and work under EU law because the children would otherwise be deprived of the genuine enjoyment of their rights as citizens of the Union. ${ }^{5}$ This new approach to jurisdiction justifying the Court's interference on the grounds of the severity of Member States' interference with EU citizens' rights ${ }^{6}$ rather than on a pure cross-border logic was generally reconfirmed by the Court's Third Chamber in McCarthy without, however, bringing about the same result: the judges found that an adult EU citizen could not rely on EU law to regularise the residence of her Jamaican husband in the United Kingdom in the absence of any cross-border movement. Her dual citizenship in itself was not accepted as a sufficient linking factor with EU law. ${ }^{7}$ Moreover, Mrs. McCarthy's inability to have proper family life in the UK, curiously, was not viewed by the Court as a deprivation of the genuine enjoyment of EU citizenship rights. ${ }^{8}$

Following a brief presentation of the Ruiz Zambrano and McCarthy judgments (2.) this contribution turns to the analysis of their implications for the drawing of the borderline between national law and EU law. The new jurisdiction test these cases helped to establish has clear implications for the scope of application of the

\footnotetext{
3) Hanf, D., "Reverse Discrimination" in EU Law: Constitutional Aberation, Constitutional Necessity, or Judicial Choice', 2011 MJ 18(1-2), pp. 26-61; Van Elsuwege, P. \& Adam, S., 'Situations purement internes, discriminations à rebours et collectivités autonomes après l'arrêt sur l'Assurances soins flamande', 2008 Cahiers de droit européen, pp. 655-711; Tryfonidou, A., 'Reverse Discrimination in Purely Internal Situations: An Incongruity in a Citizens' Europe', 2008 LIEI 35(1), pp. 43-67.

4) And following Rottmann in this respect, see case C-135/08, Janko Rottmann v. Freistaat Bayern [2010] ECR I-1449.

5) Case C-34/09, Gerardo Ruiz Zambrano v. Office national de l'emploi, [2011] ECR I-0000.

6) Kochenov, D., 'A Real European Citizenship, A New Jurisdiction Test, A Novel Chapter of the Development of the Union in Europe', 2011 CJEL 18 (forthcoming).

7) Case C-434/09, Shirley McCarthy v. Secretary of State for the Home Department, [2011] ECR I-0000, paras. 40-41.
}

8) Ibid., para. 49. 
rules governing family reunification of EU citizens (3.). The section that follows is devoted to the paradoxical implications of reverse discrimination in the field of family reunification (4.). It is often so that EU law is a vital opening to avoid restrictive national regulation which creates a reality where Union citizens that are unable to prove a link with EU law are sometimes subjected to stricter rules on family reunification in comparison to third country nationals that are lawfully residing in the territory of the Union. This is difficult to accept in light of principles such as legal certainty, equality and the protection of fundamental rights. Having demonstrated the imperfections of the current state of regulation (5.), the contribution points at the limits of judicial intervention for the protection of family reunification as a fundamental human right (6.).

\section{Ruiz Zambrano and McCarthy Compared}

\subsection{Factual Background}

Mr. Ruiz Zambrano, his wife and their three-year old son, all Colombian nationals, came to Belgium in 1999 and applied for asylum due to the civil war in Colombia. The Belgian authorities refused their application and ordered them to leave the country. Significantly, a non-refoulement clause was included into the decision of the competent authorities due to the ongoing troubles in Colombia. ${ }^{9}$ So the family remained in Belgium without any work or residence permits. They were officially registered with the municipality where they settled ${ }^{10}$ and Mr. Ruiz Zambrano worked on a permanent employment contract paying all the required taxes and social security contributions. ${ }^{11}$ In the meanwhile, his wife gave birth to two more children (Diego and Jessica) who acquired Belgian nationality according to a provision of the Belgian Nationality Code aiming at the reduction of statelessness. ${ }^{12}$ Numerous attempts of the family to regularise their situation in Belgium were unsuccessful. ${ }^{13}$

When Mr. Ruiz Zambrano's employment contract was temporarily suspended in 2005, after five years of continuous employment, he applied for unemployment benefits with the National Employment Office. This application was rejected since he was not in possession of a work permit. Moreover, the Belgian

\footnotetext{
9) Case C-34/09, Ruiz Zambrano [2011] ECR I-0000, para. 20.

10) Ibid., para. 22.

11) Ibid., para. 23.

12) Since the children were not registered with the Colombian consulate, they did not acquire Colombian nationality and were thus stateless in the eyes of the Belgian authorities. The reluctance of Mr. Ruiz Zambrano to register his children as Colombian nationals is quite understandable, given what he had to go through in that country, where his first sun was kidnapped by the guerillas and kept hostage for a week: See para. 16 of the judgment.

13) Ibid., para. 23.
} 
authorities obliged his company to fire him on the spot, ${ }^{14}$ leaving the family with no means of subsistence. Mr. Ruiz Zambrano challenged this decision claiming that as a parent of minor Belgian children, he was entitled to reside and work in Belgium on the basis of the provisions related to EU citizenship. ${ }^{15}$ The Employment Tribunal in Brussels submitted a preliminary reference asking the CJEU whether the situation at issue fell within the scope of EU law, notwithstanding the fact that the children never exercised their free movement rights. ${ }^{16}$

Shirley McCarthy was born and has always resided in her native United Kingdom relying on social assistance. Following her marriage to a Jamaican national who could not obtain a leave to remain under UK laws, she activated her dormant Irish nationality expecting to create a cross-border situation to benefit from more lenient EU family reunification rules. Together with her husband, she applied for a residence permit in the UK on the basis of EU law as a migrant EU citizen of Irish nationality accompanied by a spouse. The Secretary of State refused these applications on the ground that Mrs. McCarthy did not qualify as a worker, self-employed person or self-sufficient person under EU law. ${ }^{17}$ She was in receipt of State benefits, and has never stayed in any country other than the UK. Since she was deemed as unable to benefit from EU law in such a situation, her husband could not have any derivative residence right either. The referring court essentially asked whether the situation of Mrs. McCarthy fell within the scope of EU law by virtue of her dual nationality notwithstanding the fact that she never exercised her right of free movement and always resided in one Member State of which she is a national.

\subsection{The Diametrically Opposed Opinions of AGs Sharpston and Kokott}

Despite the largely comparable questions regarding the scope of application of EU law, the opinions delivered by AG Sharpston in Ruiz Zambrano and by AG Kokott in $M c$ Carthy are strikingly different. Whereas Sharpston argued that citizenship in itself could be a sufficient connecting factor to EU law irrespective of the existence of an a priori movement between the Member States, ${ }^{18}$ AG Kokott restated an old mantra that EU citizenship law only applies in a cross-border context. ${ }^{19}$ These divergent visions reflect a long-standing debate in academic literature regarding the viability of the principle that the Treaty provisions on free movement of persons - including the rules on EU citizenship - cannot be applied to situations which are confined in all relevant respects to a single Member State. In particular, it has been argued by many that the (potential) existence of reverse

14) Ibid., para 27.

15) Ibid., para. 34.

16) Ibid., para. 35.

17) Case C-434/09, Shirley McCarthy [2011] ECR I-0000, paras. 14-17.

18) Opinion of Advocate General Sharpston in Case C-34/09, Ruiz Zambrano, paras. 100-101.

19) Opinion of Advocate General Kokott in Case C-434/09, Shirley McCarthy, paras. 30-31. 
discrimination as a result of the interaction between EU law and national law is difficult to reconcile with a Union that is based on the rule of law and the principle of equal treatment, let alone with the Internal Market thinking. ${ }^{20}$

Developing her line of argument familiar from the earlier Flemish Care Insurance case, ${ }^{21}$ AG Sharpston delivered an Opinion of remarkable sophistication and clarity, critically pointing out the practical problems of distinguishing between purely internal and cross-border situations under the Court's traditional case law. ${ }^{22}$

With a view to avoiding instances where the classification of some situation as wholly internal or cross-border is tenuous at best, the AG recommended the Court to recognize the existence of a free-standing right of residence for EU citizens and, consequently, their family members upon which they are dependent to benefit from such right, ${ }^{23}$ thus 'seriously addressing the issue of reverse discrimination'. ${ }^{24}$ AG Kokott expressed contrarian views arguing in her Opinion in $M c$ Carthy that EU citizens cannot derive a right of residence vis-à-vis their Member State of nationality in the absence of a cross-border element. ${ }^{25}$ The mere fact that Mrs. McCarthy also had an Irish passport was deemed insufficient to satisfy this criterion because, from the point of view of the law on residence, she is in the same situation as other British nationals who never left their country of origin. ${ }^{26}$

With regard to reverse discrimination, AG Kokott merely recalled the Court's established position that 'EU law provides no means of dealing with this problem. ${ }^{27}$ Significantly, she also acknowledged that 'it cannot be ruled out that the Court will review its case-law when the occasion arises' but considered that the $M c$ Carthy case did not provide the right context for such a step. ${ }^{28}$ AG Sharpston, on the other hand, proposed to remedy reverse discrimination on the basis of Article 18 TFEU when three cumulative conditions are fulfilled. ${ }^{29}$ First, the claimant has to be a 'static' Union citizen whose situation is comparable, in all other material respects, to that of his migrant compatriots. Second, the reverse discrimination would have to entail a violation of a fundamental right protected under EU law. Third, Article 18 TFEU would only be applied when national law does not afford adequate fundamental rights protection.

\footnotetext{
20) Kochenov, D., Citizenship without Respect: The EU's Troubled Equality Ideal, Jean Monnet Working Paper (NYU Law School 2010) 08/10, pp. 34-54 (and the literature cited therein).

21) Case C-212/96, Government of the French Community and Walloon Government v. Flemish Government [2008] ECR I-1683; Van Elsuwege \& Adam, supra note 16, p. 327.

22) Opinion of Advocate General Sharpston in Case C-34/09, Ruiz Zambrano, paras. 85-88.

23) Ibid., para. 101.

24) Ibid., para. 139.

25) Opinion of Advocate General Kokott in Case C-434/09, Shirley McCarthy, para. 31.

26) Ibid., para. 37.

27) Ibid., para. 40.

28) Ibid., paras. 42-43.

29) Opinion of Advocate General Sharpston in Case C-34/09, Ruiz Zambrano, paras. 145-148.
} 
Finally, both Sharpston and Kokott dealt with the question whether the fundamental right to family life played a role in the two cases. According to settled case law, EU fundamental rights may only be invoked when the contested measure comes within the scope of application of EU law. ${ }^{30}$ Given the perceived absence of such a triggering factor in McCarthy, AG Kokott bluntly observed that this was not an issue of EU law and exclusively belonged to the jurisdiction of the national courts and the European Court of Human Rights. ${ }^{31}$ In contrast, AG Sharpston proposed to extend the scope of EU fundamental rights protection to all areas falling within the scope of material EU competence. ${ }^{32}$ However, she also acknowledged that, at the time of the relevant facts, the fundamental right to family life could not be invoked as a free-standing right. Such a development 'requires both an evolution in the case-law and an unequivocal statement from the constituent powers of the EU (its Member States)'. ${ }^{33}$

\subsection{The Judgments: Similar Reasoning Leading To Opposing Outcomes}

The divergent perspectives of the Advocates General are, to a certain extent, reflected in the respective judgments of the Court of Justice. Without opening the gates to the unconditional application of EU citizenship rules to all purely internal situations, and following its decision in Rottmann decided a year earlier, ${ }^{34}$ the Grand Chamber in Ruiz Zambrano concluded that 'Article 20 TFEU precludes national measures which have the effect to depriving citizens of the Union of the genuine enjoyment of the substance of the rights conferred by virtue of their status as citizens of the Union.'. ${ }^{35}$ Just as it did earlier in Rottmann, rather than trying to construct a cross-border situation, the Court focused on the implications of the national measures for the effective exercise of EU citizenship rights. Instead of a cross-border element, the severity of Member States' interference with EU citizenship rights was used as the decisive criterion to bring a situation within the ambit of EU law. Proceeding from the observation that Belgian children would be unable to benefit from their rights as EU citizens when Ruiz Zambrano is driven by the national authorities outside of the territory of the Union, the Court concluded that Mr. Ruiz Zambrano could derive work and residence rights from EU law. This right was based directly and exclusively on Article 20

\footnotetext{
30) Case 5/88, Wachauf [1989] ECR 2609, para. 22; Case C-2/92, Bostock [1994] ECR I-955, para. 16; Joined Cases C-20/00 and C-64/00, Booker Aquaculture and Hydro Seafood [2003] ECR I-7411, para. 68.

31) Opinion of Advocate General Kokott in Case C-434/09, Shirley McCarthy, para. 60.

32) Opinion of Advocate General Sharpston in Case C-34/09, Ruiz Zambrano, para. 163.

33) Ibid. para. 173.

34) Case C-135/08, Rottmann [2010] ECR I-1449. Also: Kochenov, D., 'Annotation of Case C-135/08 Rottmann', 2010 CMLRev. 47(6), pp. 1831-1846; De Groot, G.-R., 'Overwegingen over de Janko Rottmann-beslissing van het Europese Hof van Justitie’, 2010 Asiel \& migrantenrecht 1(5-6), pp. 293300.

35) Case C-34/09, Ruiz Zambrano [2011] ECR I-0000, para. 42.
} 
TFEU. The Court reasonably concluded that Directive 2004/38, which includes an explicit cross-border requirement and specific provisions on residence rights for third-country family members, 'does not apply to a situation such as that at issue in the main proceedings. ${ }^{36}$

The Court followed the same reasoning in McCarthy. Firstly, it confirmed that Directive 2004/38 only applies to citizens who move to or reside in a Member State other than that of which they are a national. ${ }^{37}$ The conditions laid down in Directive 2004/38 cannot apply to static Union citizens because, as a principle of international law, Member States cannot refuse its own nationals the right to reside in its territory. ${ }^{38}$ Hence, a Union citizen who has never exercised his right of free movement and has always resided in the Member State of which he is a national falls outside the scope of application of Directive 2004/38. The mere fact that a static Union citizen is a national of more than one Member State does not change this situation. ${ }^{39}$

However, just as in Ruiz Zambrano, as a result of the hierarchy of norms, the non-application of Directive 2004/38 does not necessarily imply that static EU citizens cannot derive any rights from their EU citizenship status under primary EU law. The Court therefore examined the application of Article 21 TFEU to the case at stake - even though this was not explicitly asked by the referring court and also applied the 'genuine enjoyment test' introduced in Rottmann and Ruiz Zambrano in order to see whether the situation of Mrs. McCarthy could be brought within the scope of EU law. The Court concluded that EU citizenship precludes the adoption of national measures that 'have the effect of depriving Union citizens of the genuine enjoyment of the substance of the rights conferred by virtue of that status, or of impeding the exercise of the right to move and reside freely within the territory of the Member States' ${ }^{40}$ In other words, the traditional jurisdiction test based on cross-border situation analysis and a new test constructed around the necessity to ensure that EU citizens are not deprived of the genuine enjoyment of EU citizenship rights were applied by the Court side by side. The CJEU found that the situation of Mrs. McCarthy did not meet the requirements of either of the two. According to the Court, the failure of the British authorities to grant her a right of residence in the UK does not affect her right of free movement or any other EU citizenship right. In contrast to the Belgian children in Ruiz Zambrano, she did not face a threat to leave the territory of the Union which would make the benefit of her EU citizenship rights impossible.

\footnotetext{
36) Ibid., para. 39.

37) Case C-434/09, Shirley McCarthy [2011] ECR I-0000, paras. 31-39.

38) Ibid., para. 29. There is an obvious tension with the Ruiz Zambrano reasoning here, since international law was not invoked by the Grand Chamber in that case in a situation when Belgium was doing exactly that: refusing its own nationals a possibility to reside in the country: Kochenov, supra note 6.

39) Ibid., para. 41.

40) Ibid., para. 49 (emphasis added).
} 
Moreover, she enjoys, under a principle of international law, an unconditional right of residence in the UK as a national of this country. ${ }^{41}$ In both cases, there is a notable silence on the right to family life.

\section{The Scope of Application of EU Citizenship: Where to Draw the Boundaries?}

\subsection{The Application of the 'Cross-border' and the 'Genuine Enjoyment' Tests}

The reasoning of the CJEU in Ruiz Zambrano and McCarthy makes it clear that the boundaries between the scopes of application of EU and national law cannot any more be reduced to a simple distinction between cross-border and purely internal situations. Rather than the formal existence of a cross-border element, however artificially constructed, ${ }^{42}$ the implications of national measures for the effective reliance on EU citizenship rights ${ }^{43}$ are crucial when deciding whether or not EU law is applicable. Even with no cross-border element present, a particular situation can 'by reason of its nature and its consequences' fall within the ambit of EU law. ${ }^{44}$ In other words, the traditional cross-border situation test is complemented by the severity of interference, or 'genuine enjoyment' test.

A new test to replace (at least potentially) the old cross-border situation test of the CJEU was sorely needed..$^{45}$ Notwithstanding the fact that the Court applies a teleological interpretation of the cross-border requirement, meaning that the implications of a national measure on the actual or potential exercise of the right to move and reside in another Member State are crucial for the determination whether or not a situation falls within the scope ratione materiae of EU law, the test often failed to produce predictable and convincing results, remaining largely procedural in nature. ${ }^{46}$ Most importantly, it failed to shape clarity in the eyes of ordinary EU citizens who would otherwise find themselves in materially identical situations why some situations would fall within the scope of EU law in the eyes

\footnotetext{
41) Ibid., para. 50.

42) It is established case law that a situation of an EU citizen who never exercised her free movement rights cannot, for that reason alone, be equaled with a wholly internal situation. A long line of cases illustrates that cross-border situations can be constructed without any physical movement in space: Case C-200/02, Zhu and Chen [2004] ECR I-9925; Case C-148/02, Garcia Avello [2003] ECR I-11613; Case C-403/03, Schempp [2005] ECR I-6421. For analysis see Kochenov, supra note 20, pp. 34-52; Spaventa, E., 'Seeing the Wood despite the Trees? On the Scope of Union Citizenship and its Constitutional Effects', 2008 CMLRev 45(1), pp. 13-46, at p. 14.

43) This includes, as has been clarified in Rottmann, the very possession of the legal status of EU citizenship: Case C-135/08, Rottmann [2010] ECR I-1449, para. 42.

44) Ibid.

45) Kochenov (2011 CJEL), supra note 6.

46) Spaventa, supra note 42, p. 14; Nic Shuibhne 2002. 'The European Union and Fundamental Rights: Well in Spirit but Considerably Rumpled in Body?', in: Paul Beaumont, C. Lyons and N. Walker (Eds.), Convergence and Divergence in European Public Law, Hart, Oxford, p. 188; Kochenov, supra note 20, p. 34.
} 
of the CJEU and others would not. The Court's attempts to deploy the teleological vision of the cross-border element test with a view to diminishing the scale of reverse discrimination, however admirable, deluded the essence of its approach to the delimitation of the scopes of the two legal orders in the Union. ${ }^{47}$ A nationality of one's former wife, like in $S$ chemp $p,{ }^{48}$ could create a cross-border situation, just as a potential willingness to exercise free movement rights in the future, as in Garcia Avello. ${ }^{49}$

The main novelty of Ruiz Zambrano and McCarthy consists in the fact that building on Rottmann, they offered an alternative to cross-border thinking, which is grounded in the concept of EU citizenship as such, not in the idea of actually or potentially crossing the internal borders of the Union. ${ }^{50}$ The latter was bound to lose much of its appeal upon the creation of EU citizenship - a concept which is not economic in nature ${ }^{51}$ - and the completion of the Internal Market, making real the 'area without internal frontiers's2 the Treaties speak about. Consequently, it is only logical to look beyond the internal borders in framing the scope of EU law. And this is exactly what the Court has done, ${ }^{53}$ unfortunately without providing much information to explain this fundamental paradigm shift. It is not surprising that the new 'genuine enjoyment' and the traditional 'cross-border situation' tests overlap: the CJEU does not change the essence of the Union and respects the principle of conferral. What it does, is providing an alternative way to consider the grounds of applicability of EU law. Consequently, the absolute majority of cross-border situations could potentially come under the umbrella of the 'genuine enjoyment' test. The new test merely supplies a more logically coherent ground for the invocation of EU rules: demonstrating that the Union is simply protecting its citizens' rights from disproportionate Member State interference is infinitely more convincing than arguing that the intervention is necessary since a Union citizen in question has crossed an internal border. ${ }^{54}$

\footnotetext{
47) Tryfonidou, A., 2009. 'In Search of the Aim of the EC Free Movement of Persons Provisions: Has the Court of Justice Missed the Point?'. CMLRev. 46(5), pp. 1591-1620; Kochenov, supra note 20, pp. 47-52.

48) Case C-403/03, Schempp [2005] ECR I-6421, para. 22; Spaventa, supra note 42, p. 21.

49) Case C-148/02, Garcia Avello [2003] ECR I-11613.

50) Hailbronner, K. \& Thym, D., 'Annotation of Case C-34/09 Ruiz Zambrano', 2010 CMLRev. 48(4), pp. 1253-1271, at p. 1257; Van der Mei, A.P., Van den Boogaert, S.C.G. \& De Groot, G.R., 'De arresten Ruiz Zambrano en McCarthy. Het Hof van Justitie en het effectieve genot van EU burgerschapsrechten', 2011 NTER 17 (6), pp. 188-199.

51) But see Nic Shuibhne, N., 'The Resilience of EU Market Citizenship', 2010 CMLRev. 47(6), pp. 1597-1629.

52) Art. 26(2) TFEU.

53) This has for the first time happened in Case C-300/04, Eman and Sevinger [2006] ECR I-8055, but was forcefully reaffirmed in Case C-135/08, Rottmann [2010] ECR I-1449, where the new approach to jurisdiction has been explicitly formulated by the Court. On the former see Kochenov, D., 'The Impact of European Citizenship on the Association of the Overseas Countries and Territories with the European Community', 2009 LIEI 36(3), pp. 239-256.

54) Kochenov, supra note 6.
} 
The duality of tests to delineate the scope of application of EU citizenship law reflects the structure of the relevant Treaty provisions. Whereas the right to move and reside freely within the territory of the Member States as laid down in Article 21 TFEU and Directive 2004/38 only applies in an inter-State context, this is not necessarily the case for the non-exhaustive list of citizenship rights under Article 20 TFEU. ${ }^{55}$ From this perspective, the granting of a residence right in Ruiz Zambrano is not so much related to his children's right to reside and move within the Union but more to the full application of their citizenship rights in general. For this reason, the Court in this case explicitly refers to Article 20 TFEU and not to Article 21 TFEU. ${ }^{56}$ Moreover, any 'future exercise' of free movement rights is not mentioned. This very telling silence of the Court cannot be ignored. With regard to the situation of Mrs. McCarthy, on the other hand, the Court considered that she did not face a potential deprivation of her general citizenship rights. In contrast to the minor children of Mr. Ruiz Zambrano, who were under a de facto obligation to leave the territory of the Union unless at least their father was granted a right to reside and work, ${ }^{57} \mathrm{Mrs}$. McCarthy enjoyed a stable residence in the UK. Hence, her situation did not trigger the application of Article 20 TFEU. Moreover, in the absence of any effective cross-border element she failed to fall within the scope of Article 21 TFEU and Directive 2004/38.

The fact that there are now two tests of jurisdiction at the disposal of the Court raises questions with regard to the continued relevance of the purely internal rule. Although the regulatory autonomy of the Member States enshrined in Article 5 TEU is obviously affected, ${ }^{58}$ a parallel can be drawn, following Ankersmit and Geursen, with the functioning of the principles of equivalence and effectiveness in EU procedural law. ${ }^{59}$ Member States are free to put up any regulation as long as it does not profoundly undermine the status of EU citizenship and the rights associated therewith.

It is crucial, in this context, to have a clear idea of what 'the genuine enjoyment of the substance of rights conferred by virtue of their status as citizens of the Union' means - the Court will have to be very thorough in addressing this issue. As the law stands today, it appears that the threshold to conclude that a measure

\footnotetext{
55) The word 'inter alia' in the Article 20 TFEU enumeration of EU citizenship rights seems of fundamental importance here.

56) This is all the more remarkable because AG Sharpston did base her reasoning essentially on Article 21 TFEU.

57) Mr. Ruiz Zambrano was in possession of a temporary residence permit - valid for the duration of his action against the Belgian authorities - when the CJEU decided the case: Case C-34/09, Ruiz Zambrano [2011] ECR I-0000, para. 24.

58) Hailbronner \& Thym, supra note 50, p. 1253; Nic Shuibhne, Niamh, 'Seven Questions for Seven Paragraphs', 2011 ELRev. 36(2), pp. 161-163.

59) While Member States are free to establish their own rules of procedure, these have to respect the principles of EU law in not making the recourse to EU law impossible or more difficult than to national law: Ankersmit, L. \& Geursen, W., 'Ruiz Zambrano: De interne situatie voorbij', 2011 Asiel \& Migrantenrecht no. 4, p. 156.
} 
deprives a Union citizen of the genuine enjoyment of the rights connected with that status is rather high, covering situations where a citizen's residence in the Union, like in Ruiz Zambrano, or his/her status as citizen of the Union is at stake, like in Rottmann. It is thus impossible to be certain whether static EU citizens would receive an opportunity to invoke their EU citizenship rights with ease against their home Member States to claim, inter alia, a right to family reunification, or non-discrimination under Article 18 TFEU. Further clarifications from the CJEU are required in order to see how far the new jurisdiction test is able to stretch the scope of EU law compared with what has been covered by the old approach already. Are we speaking merely about very exceptional circumstances? The judgment of the Court in McCarthy could be interpreted as pointing in the latter direction. ${ }^{60}$ However, it could also be the case that the Court is unwilling to deploy the new approach at full power before it took a solid place in its arsenal of legal tools.$^{61}$ One thing is clear at this stage: the Court has definitely recognised the potential of EU citizenship to enlarge the material scope of EU law ${ }^{62}-a$ welcome development long awaited by some scholars. ${ }^{63}$

\subsection{Implications for the Right to Family Reunification: Remaining Question Marks}

The new approach, especially as employed by the Court in McCarthy, cannot solve all challenges, which were so clearly analysed in the Opinion of AG Sharpston in Ruiz Zambrano. This is particularly true with regard to the area of family reunification rights. Five main drawbacks can be outlined here.

Firstly, despite the Court's efforts to shape a renewed vision defining the logic behind drawing the boundaries between the scope of application of EU and national law, the 'cross-border movement' and 'genuine enjoyment' tests cannot per se rule out a feeling of legal uncertainty. After Ruiz Zambrano and McCarthy, it would be an overstatement to claim that there is clarity as to where this border lies. We still do not know in which factual situations EU law would apply through the new test helping family reunification with third country nationals. The old test does not solve the problem either, for obvious reasons. In one example, would it have made a difference if Mrs. McCarthy ever went on a holiday trip to another Member State? Would that in itself be sufficient to bring her in the scope of the Treaties? ${ }^{34}$ The Court did not follow the reasoning that Mrs. McCarthy also faced a deprivation of her EU citizenship rights since she was not required to leave the territory of the Union to live with her husband. While this might be viewed as a

\footnotetext{
60) Van Elsuwege, P., 'European Union Citizenship and the Purely Internal Rule Revisited', 2011 EUConst. 7(2), p. 314.

61) Kochenov, supra note 6.

62) Thym \& Hailbronner, supra note 50, p. 1255; Van Elsuwege (2011); Kochenov, ibid.

63) Spaventa, supra note 42 (and the literature cited therein).

64) See: AG Sharpston in Ruiz Zambrano, para. 86.
} 
logical conclusion, given that she could move to any Member State other then the UK and bring her husband along, this vision stands to be seriously criticised, since, as an economically inactive person she would not meet the residence requirements contained in the Directive, meaning that creating a 'genuine' crossborder situation was not an option. The Court is bound to address the interaction between the old and the new approaches as well as the general feeling of legal uncertainty in the upcoming cases. ${ }^{65}$

Secondly, the Court's arguments to differentiate between Ruiz Zambrano and McCarthy are 'frustratingly opaque'. ${ }^{66}$ It did not refer to the rule of international law that a country cannot expel its own citizens in its Ruiz Zambrano decision whereas this constituted a key argument to conclude that EU law was not applicable in the case of $M c$ Carthy ${ }^{67}$ Should the Court's observations regarding the importance of international law for the residence rights of own nationals in the Member States be taken seriously, there is obviously no room for attaching any conditions to this right. In other words, it objectively does not matter whether nationals have resources or not in order to stay in their Member State of nationality, since arguing to the contrary would result in deportations of the unemployed. The Court also fails to explain the differentiation between the conditions for granting a residence right to third country national family members under Article 20 or Article 21 TFEU. In cross-border situations, the application of Article 21 TFEU and Directive 2004/38 implies that third country family members can benefit from a right of residence on the condition that they have sufficient resources and a sickness insurance so that they do not become an unreasonable burden to the public finances of the host Member State. ${ }^{68}$ In Ruiz Zambrano the Court did not refer to those conditions for the simple reason that they are laid down in Directive 2004/38, which was not applicable to that case given the absence of any cross-border movement. Hence, by deriving a right of residence on the basis of Article 20 TFEU strict residence conditions for third country family members do not apply. Of course, the Court granted Mr. Ruiz Zambrano a right to work, but this in itself seems not necessarily a guarantee for sufficient resources.

Thirdly, the Court's emphasis on the right to reside in the territory of the Union in $M c$ Carthy puts the right to family life in an unfortunate perspective. In

\footnotetext{
65) See, in particular, pending case C-256/11, Murat Derici, Vishaka Heiml, Alban Kokollari, Izunna Emmanuel Maduike and Dragica Stevic v. Bundesminister für Inneres.

66) Lansbergen, A. \& Miller, N., 'European Citizenship Rights in Internal Situations: An Ambiguous Revolution?', 2011 EUConst, 7 (2), p. 287.

67) Kochenov, supra note 6.

68) This was, for instance, the case in Zhu and Chen, where it was assumed that little Catherine, who had acquired the Irish nationality by being born in Belfast but never left the UK, exercised her right of free movement under Article 21 TFEU from birth. In this case, the Court observed that Catherine and her Chinese mother had sufficient resources and a sickness insurance to claim a residence right under EU citizenship law.
} 
fact, not paying attention to the core issue of the case, which is the right of residence in the UK of Mr. McCarthy - a Jamaican national - results in a total misrepresentation of the ruling of Ruiz Zambrano by the Chamber in this case. The rule formulated by the Grand Chamber in Ruiz Zambrano is very simple: Member State measures which make the exercise of EU citizenship rights impossible come within the scope of EU law and it does not matter whether the person in question is in a cross-border situation or not. This is an issue of principle - not a question which concerns a particular right, which happened to be the right to reside in the territory of the Union in the context of the Ruiz Zambrano factual situation. ${ }^{69}$ It is undisputable, should we read the Treaties carefully, that the right to reside in the Union is by far not the only EU citizenship right. To claim that the situation of Mrs. McCarthy is outside the scope of EU law because this particular right is not deemed to be infringed without scrutinising the effects of UK policy on her other rights is to reduce the rule of Ruiz Zambrano to its factual finding. To be convincing the Court had to assess whether the UK decision amounted to depriving Mrs. McCarthy of her EU citizenship rights. Is the Court telling us that the right to family life is not covered? Or can it be - which would be very cynical indeed, that only economically active EU citizens have a right to family life?

Fourthly, a number of grey zones with potentially far-reaching implications emerge out of the Ruiz Zambrano/McCarthy duo. They concern the breadth of reading of the Ruiz Zambrano rule by the national authorities. While the majority of the Member States, including Belgium, now prevent the acquisition of their nationality by children who could obtain some other nationality should their parents register them with the consulate, it is clear that the easiest way to acquire a Member State nationality and, by consequence, EU citizenship, is to be born to an EU citizen parent. The potential implications of Ruiz Zambrano for mixed couples composed of an EU citizen and a third country national are overwhelming indeed. ${ }^{70}$ The presumption that EU citizen children are not forced to leave the territory of the Union if one of their parents is deported, as the Dutch courts regrettably assume, ${ }^{71}$ is unfounded. Ruiz Zambrano was about the father only, but its ruling can legitimately be extended to cover the mother of the children too. Consequently, both parents will see their situation regularised. This is only normal not to ruin the family and is in accordance with ECtHR jurisprudence on Article 8 ECHR..$^{72}$ In this context, it would be unreasonable to assume that the essence of the family would be different if one of the parents were an EU citizen. In other words, mixed EU citizen / third country national couples (or former couples)

\footnotetext{
69) Kochenov, supra note 6.

70) See: Davies, G., 'Ruiz Zambrano en de non-EU ouders van (bijna) Nederlandse kinderen', 2011 Asielen Migrantenrecht, forthcoming.

71) E.g. AWB 10/37591.

72) ECtHR, Gülv. Switzerland, Application 23218/94, para. 32.
} 
with EU citizen children are clearly within the ambit of the Ruiz Zambrano rule. A reaffirmation of this would seem to be still necessary from the CJEU. Before it comes, however, Member States' own vision will prevail: the Dutch courts will continue deporting the mothers from their children. ${ }^{73}$

Finally, the Court's new approach does not solve the issue of reverse discrimination. The introduction of the 'genuine enjoyment test' reduces the margin for reverse discrimination to a certain extent but, as illustrated in McCarthy, it may appear rather difficult to prove that a national measure deprives a person of his EU citizenship rights. As a result, a static Member State national such as Mrs. McCarthy cannot claim a family reunification right under EU law whereas a person such as Mr. Carpenter, who occasionally provides services to persons established in other EU Member States, can invoke such a right. ${ }^{74}$ This differentiation may be regarded as a logical consequence of the division of powers between the Union and the Member States, ${ }^{75}$ but the rather blurred boundaries between situations falling inside or outside the scope of application of EU law largely undermine the legitimacy and predictability of the Court's decisions. ${ }^{76}$

\section{Paradoxical Consequences of Reverse Discrimination}

Static EU citizens sometimes not only face stricter family reunification conditions than their migrant compatriots and nationals of other Member States. They may also be in a less advantageous position in comparison to third country nationals residing lawfully in the territory of a Member State. The latter can benefit from the conditions laid down in Directive 2003/86 on the right to family reunification within the Union ${ }^{77}$ or from more beneficial provisions included in international agreements. ${ }^{78}$ This Directive applies to third-country nationals holding a residence permit for at least one year with a prospect of permanent residence and explicitly excludes family members of Union citizens from its scope of application. ${ }^{79}$ It lays down detailed requirements for the exercise of the right to family

\footnotetext{
73) The approach in a number of other Member States is different to the Dutch extreme. See e.g. the decision of Lady Hale of the High Court of England and Wales in ZH (Tanzania) v. SSHD [2011] UKSC 4.

74) Case C-60/00, Carpenter [2002] ECR I-6279.

75) Hanf, supra note 3, p. 29.

76) Tryfonidou, supra note 47 , p. 34.

77) Council Directive 2003/86/EC of 22 September 2003, on the right to family reunification, $O J$ (2003) L251/12. Significantly, this Directive is not applicable in Denmark, Ireland and the United Kingdom.

78) Article 3 (4) of Directive 2003/86. Of particular significance is the association agreement with Turkey and the rules on family reunification adopted by the EU-Turkey Association Council. In a recent judgment, a Dutch national court concluded that the right to family reunification for legally resident Turkish citizens cannot be subject to forced integration measures because such an obligation is contrary to various provisions of the association law between the EU and Turkey. See: Centrale Raad van Beroep, 16 August 2011, LJN: BR4959.

79) Article 3 (3) of Directive 2003/86.
} 
reunification such as evidence of normal accommodation, sickness insurance and sufficient resources to maintain the family. ${ }^{80}$ These being satisfied, Member States may only reject an application for entry and residence on grounds of public policy, public security and public health. ${ }^{81}$ Besides the obvious parallels with the conditions for family reunification of migrant EU citizens, there are also important differences. So the third country national's right to family reunification is limited to the spouse and unmarried minor children. ${ }^{82}$ Moreover, Member States may require family members to participate in integration measures ${ }^{83}$ as well as apply a waiting period of up to two years. ${ }^{84}$

In its Chakroun judgment, the CJEU clarified that Directive 2003/86 imposes 'precise positive obligations' on the Member States, which requires them to authorise family reunification 'without being left a margin of appreciation' when the necessary conditions are fulfilled.$^{85}$ In evaluating an applicant's financial resources, Member States may indicate a certain reference amount but this cannot be considered a fixed threshold below which all family reunifications can be refused irrespective of an actual examination of individual circumstances. Accordingly, a requirement to earn at least $120 \%$ of the minimum wage in the Netherlands was deemed to be against the spirit and wording of Directive 2003/86. ${ }^{86}$

Significantly, the protection offered by EU law to migrant EU citizens under the conditions of Directive 2004/38 or to third-country nationals on the basis of Directive 2003/86 does not exist when it comes to static Member State nationals unless, following Ruiz Zambrano, family reunification is crucial to preserve the genuine enjoyment of their EU citizenship rights. While some Member States, such as Italy do not allow reverse discrimination in this domain, others, such as the Netherlands or Germany, Cyprus and Lithuania ${ }^{87}$ provide for family reunification rules which are much stricter than their EU counterparts ${ }^{88}$ and are at times de facto basically impossible to satisfy. For instance, the condition of passing an

\footnotetext{
80) Article 7 (1) of Directive 2003/86.

81) Article 6 of Directive 2003/86.

82) For migrant EU citizens falling within the scope of Directive 2004/38, this also includes forms of registered partnership and dependent direct relatives in the ascending and descending line of both the Union citizen and his spouse or partner. See: Article 2 of Directive 2004/38, OJ (2004) L 158/77.

83) Art. 7(2) of Directive 2003/86.

84) Art. 8(1) of Directive 2003/86.

85) Case C-578/08, Chakroun [2010] ECR I-1839, para. 41.

86) Ibid., paras. 48-52.

87) Report from the Commission to the European Parliament and the Council on the application of Directive 2003/86/EC on the right to family reunification, COM (2008) 610 final, p. 4.

88) It is noteworthy that in Belgium, the Council of State (Conseil d'état) referred to the Ruiz Zambrano ruling to conclude that reverse discrimination resulting from a draft law on the introduction of stricter conditions for family reunification would be contrary to the provisions of EU law. See: Avis du Conseil d'Etat No. 49 356/4, doc. 53 0443/015, 4 April 2011, p. 3 available at: <http://www.lachambre.be/ FLWB/pdf/53/0443/53K0443015.pdf> However, this non-binding advice, which was published before the outcome in $M c$ Carthy, was not followed by the legislator. The new law on family reunification includes stronger conditions for family reunification for 'static' Belgian citizens, such as a $120 \%$ minimum income
} 
integration test in Dutch (!) by the spouse at the Netherlands embassy in his country of nationality before entering the country makes family reunification of static Dutch nationals with persons coming from the states covered by this requirement de facto impossible: as one easily discovers, trying to find a Dutch teacher in Uzbekistan, Micronesia, or South Sudan is not an easy task. ${ }^{89}$

This approach of the national legislator coupled with the influence of EU law amounts to endowing third country nationals with much better possibilities for family reunification than own nationals who cannot claim a link with EU law. Consequently, third country nationals with family members abroad may be deterred from naturalisation. This is a rather paradoxical situation, especially taking into account that naturalisation is often regarded as the best guarantee for the successful integration of immigrants in the society of their host state..$^{90}$ In the context of its pre-accession process, for instance, the European Commission recommended the candidate countries to facilitate their naturalisation conditions in order to promote the integration of third-country nationals. ${ }^{91}$ It could, therefore, be a rather unpleasant surprise for a naturalised person to be confronted with tougher requirements for family reunification. Sporadic attempts of the national courts to help nationals in such situation by disregarding their EU citizenship make the issue even more acute. ${ }^{92}$

A specific problem thus exists for persons holding a dual nationality, including the nationality of an EU Member State on the one hand and the nationality of a third country on the other hand..$^{93}$ Since the text of Directive 2003/86 knows no rules on dual nationals, the settled case law of the CJEU that citizenship of the Union is the primary status of a Member State national becomes the starting point. In this context Dutch courts concluded on a number of occasions that the Directive does not apply to Dutchmen also having a non-EU nationality. ${ }^{94}$ While recognising that this indeed implies a loss of family reunification rights under Directive 2003/86, it is argued that this is compensated by the acquisition of new

requirement, in comparison to other EU citizens and Belgian citizens falling within the scope of EU law. See: <http://www.kruispuntmi.be/vreemdelingenrecht/wegwijs.aspx?id=14758>.

89) Moreover, civic integration course materials are only available in 18 languages: Chinese, Dari, English, French, Indonesian, Moroccan, Pashto, Portuguese, Russian, Spanish, Somali, Arabic, Tai, Turkish, Urdu, Vietnamese, Kurdish, and Berber. Many thanks to Daan Beltman for this information.

90) Carens, J.H. Culture, Citizenship, and Community, Oxford: OUP 2000; Groenendijk, K., 'Legal Concepts of Integration in EU Migration Law', 2004 EJML 6(2), pp. 111-126.

91) Van Elsuwege, P. From Soviet Republics to EU Member States. A Legal and Political Assessment of the Baltic States' Accession to the European Union, Leiden: Brill 2008, p. 421.

92) Aliens Chamber Amsterdam 16 November 2005, Jurisprudentie Vreemdelingenrecht 2006, 28; Aliens Chamber District Court Haarlem 21 December 2005, AWB 05/299, LJN: AU8416.

93) See Kochenov, D., 'Dual Nationality in the EU: An Argument for Tolerance', 2011 ELJ 17(3), pp. 323-343; Groenendijk, supra note 1, pp. 227-230.

94) Raad van State (Council of State), 29 March 2006, JV 2006, 172, LJN AW1795, and 2 December 2008, nr. 200806120/1 (www.raadvanstate.nl); LJN BC9451, Rechtbank's-Gravenhage, AWB 07/33161, 1 April 2008; LJN BK9140, Centrale Raad van Beroep, 07/6222 WWB, 15 December 2009. 
rights under EU citizenship law. ${ }^{95}$ Of course, this is under the condition that the person concerned satisfies the criteria of the cross-border or genuine enjoyment test. Hence, it is still possible that a Moroccan-Dutch national living in the Netherlands faces tougher conditions on family reunification than a migrant of only Moroccan nationality living in the same country.

Exploiting the fact that falling within the scope of EU law makes family reunification much easier for EU citizens in a number of countries, tabloids fill up with reports of 'abuse of rights', i.e. nationals moving to other Member States only to benefit from easier family reunification requirements. ${ }^{96}$ Even the Council criticised such 'abuse of free movement rights'.$^{97}$ Not surprisingly, such reports mostly concern the nationals of the countries where family reunification for static EU citizens is obstructed. In the Netherlands it is a 'Belgian route', in Denmark - a Swedish one. ${ }^{98}$ The ability for EU citizens to rely of EU rules is reinforced by the broad interpretation of the cross-border situations by the Court. ${ }^{99}$ However which might seem counter-intuitive, especially after so much attention has been paid to this phenomenon - an authoritative study concluded that any reliable evidence of the existence of such phenomenon in the first place is actually missing. ${ }^{100}$ An obvious solution to the invented problem, which is hardly ever discussed politically, is simply to stop treating 'static' EU citizens worse than others. ${ }^{101}$

\section{A Gap in the EU Legal Framework on Family Reunification?}

The phenomenon of reverse discrimination is usually regarded as an unavoidable consequence of the division of competences between the Union and the Member States. ${ }^{102}$ However, nothing seems to prevent the Member States to regulate the right to family reunification for all EU citizens. After all, Article 79 TFEU provides an explicit legal basis to regulate the conditions of entry and residence of

\footnotetext{
95) LJN BC9451, Rechtbank's-Gravenhage, AWB 07/33161, 1 April 2008, para. 2.28.

96) For analyses see Groenendijk, K. \& Fernhout, R., 'Vrij verkeer, Europa-route en omgekeerde discriminatie: Wie houdt wie voor de gek?', $2010 A \& M R$ 25(1), pp. 4-17; Bierbach, J.B., 'European Citizens' Third-Country Family Members and Community Law', 2008 EuConst 4(2), pp. 344-362.

97) Council Document 13467/09, p. 10.

98) For the analysis of the Dutch context: Bierbach (2008); Vanvoorden, K., 'Betekenen de arresten Jia en Eind het einde van de België-route?', 2008 Migrantenrecht 23(3), pp. 84-93.

99) So economic activity after moving back to one's Member State of nationality is not required, for instance, in order to fall within such scope. See: Case C-291/05, Eind [2007] ECR I-10719.

100) Groenendijk \& Fernhout, supra note 96, p. 13.

101) This was the recommendation of the Dutch Raad van State: Advies van de Raad van State of 1 July 2005, Tweede Kamer, vergaderjaar 2005-2006, 30 308, nr. 4. This recommendation fell on a deaf ear.

102) Geelhoed, L.A. 'De vrijheid van personenverkeer en de interne situatie: maatschappelijke dynamiek en juridische rafels', in: Manunza, E. \& Senden, L. (eds.), De EU: De interstatelijkheid voorbij? Nijmegen: Wolf Legal Publishers 2006, pp. 31-49, 49; Lord Slynn, Introducing a European Legal Order, London: Stevens and Sons 1992, p. 99.
} 
third country nationals 'including for the purpose of family reunification'. This provision seems not necessarily limited to situations of family reunification between third country nationals but may also include family reunification between (static) Union citizens and their third country family members. In this respect, it is also interesting to recall the negotiation history of the existing family reunification directive. The first Commission proposal explicitly included a right to family reunification for static Union citizens in an attempt to prevent situations of reverse discrimination:

\begin{abstract}
The family reunification of Union citizens who do not exercise their right to free movement of persons has hitherto been subject solely to national rules. This situation generates an unwarranted difference in treatment between the family of Union citizens who have not exercised their right to free movement and have stayed in the country of their nationality and those who have exercised their right to free movement. National law in some circumstances regulates the family reunification of its own nationals more restrictively than Community law. As Union citizenship is indivisible, the gap must be filled. This Article accordingly allows the family members of Union citizens to enjoy the benefit of the relevant provisions of Community law in matters of family reunification. ${ }^{103}$
\end{abstract}

This provision was deleted in an amended proposal, mainly because the Commission in the meantime had started with the drafting of its citizen's Directive. ${ }^{104}$ Accordingly, the alignment of the rights of all Union citizens to family reunification was postponed indefinitely. Hence, it appears that political will rather than competence excludes an EU solution to deal with reverse discrimination in this field.

In the current political climate in Europe it is not surprising that harmonisation of family reunification rules is not on the agenda. A choice for the illusion of control ${ }^{105}$ prevails over the desire to ensure equal treatment for all EU citizens. Indeed, objections to not using the option to harmonise seem misconceived, since they assume the autonomy of the Member States in immigration issues which is now severely constrained by the maturing of the Internal Market, and EU citizenship. ${ }^{106}$ Treating own nationals in family reunification matters worse than migrant EU citizens and even third country nationals is hard to justify. Arguably, such regulation persists for uniquely populist reasons and comes close to racism: it is believed that second and third generation migrants are more likely to have a nonEU partner than 'white' citizens. The real face of reverse discrimination is thus quite an ugly one. Yet, the involvement of the Member States in solving this issue in the long term is indispensable: the gap in the EU-level regulation has to be filled.

\footnotetext{
103) Proposal of a Council Directive on Family Reunification, COM (1999) 638 final, p. 14.

104) Amended Proposal of a Council Directive on Family Reunification, COM (2002) 225 final, p. 3.

105) Kochenov, D., Rounding up the Circle: The Mutation of Member States' Nationalities under Pressure from EU Citizenship, EUI RSCAS Paper 2010, pp. 20-22.

106) Kostakopoulou, D., 'European Union Citizenship: Writing the Future', 2007 ELJ 13(5), pp. 623646.
} 
In the meantime, the Court of Justice tackles the most problematic examples of reverse discrimination by extending the scope of application of EU citizenship rules to certain purely internal situations. ${ }^{107}$ It is legitimate to ask whether this is a task of the Court. ${ }^{108}$ Solving issues of reverse discrimination unavoidably implies a further harmonisation of national immigration law and this cannot be done without the involvement of the Member States and the Union legislator. ${ }^{109}$ As long as the Member States do not take their responsibility in this field, the Court is obliged to work with imperfect jurisdiction tests with all its consequences of legal uncertainty.

\section{Family Reunification as a Fundamental Human Right?}

Both Ruiz Zambrano and McCarthy deal with the issues at hand exclusively from a terribly narrow perspective of EU citizenship law and ignore the human rights dimension of the right to family reunification. This may seem somewhat surprising given the importance attributed to this issue in the Court's own case law. On several occasions, the Court confirmed that the right to respect for family life within the meaning of Article $8 \mathrm{ECHR}$ is among the fundamental rights which are protected under EU law. ${ }^{110}$ Moreover, the Charter of Fundamental Rights, which acquired a legally binding status under the Treaty of Lisbon, ${ }^{111}$ includes numerous references to respect for family life and the rights of the child. ${ }^{112}$ However, EU fundamental rights may only be invoked with regard to measures adopted by the EU institutions and acts of the Member States that fall 'within the field of application of EU law'. ${ }^{113}$ In other words, a connection with some other provision of EU law is indispensable to activate it. The perceived lack of such a connection in $M c$ Carthy explains the absence of any fundamental rights scrutiny

\footnotetext{
107) It would indeed be very difficult to accept that EU law applies to the situation of $Z h u$ and Chen, who never left the territory of the United Kingdom, and not to Ruiz Zambrano. See: Van Elsuwege P., 'Shifting the Boundaries? European Union Citizenship and the Scope of Application of EU Law', 2011 LIEI 38 (3), pp. 263-276.

108) Van der Mei, A.P., 'Combating Reverse Discrimination. Who Should do the Job?', 2009 MJ 16(4), pp. 379-382.

109) So far, attempts to create coherent EU migration policy via legislation have not been successful: Carrera, S. et al., Labour Immigration Policy in the EU: A Renewed Agenda for Europe 2020, CEPS Policy Brief 2011, p. 1.

110) Case C-60/00, Carpenter [2002] ECR I-6279 para. 41; Case C-540/03, European Parliament v. Council [2006] ECR I-5769, para. 52; Case C-459/99, MRAX [2002] ECR I-6591, para. 53; Case C-127/08, Metock [2008] ECR I-6241, para. 62; Case C-291/05, Eind [2007] ECR I-10719, para. 44. 111) Article 6 TEU.

112) Article 7 (respect for private and family life); Article 9 (right to marry and right to found a family); Article 33 (family and professional life); Article 24 (rights of the child).

113) Tridimas, T., The General Principles of EU Law, Oxford: OUP 2005, p. 39; Lenaerts, K. \& GutierrezFons, J.A., 'The Constitutional Allocation of Powers and General Principles of EU Law', 2010 CMLRev. 47(6), pp. 1629-1670, at p. 1659.
} 
on the part of the CJEU. ${ }^{114}$ In contrast, the situation of Mr. Ruiz Zambrano came within the ambit of EU law, but here as well respect for family life was apparently not a conclusive argument to grant employment and residence rights to the third country family members.

The Court's ignorance of this indispensable fundamental rights case-law may be explained by the important differences between the right to family reunification following from the application of EU citizenship law in comparison to the protection offered under Article $8 \mathrm{ECHR}$. The human rights approach is essentially based on a balancing exercise between the State interests to control the entry, residence and expulsion of non-nationals, on the one hand, and the individual circumstances of the family, on the other hand. In other words, Article 8 ECHR does not include a clear-cut right to family reunification but only imposes a minimum level of protection to be respected by the Member States. Whether or not a national measure actually violates Article 8 ECHR largely depends upon the particular circumstances of each case. In this respect, the European Court of Human Rights (ECtHR) provides a wide margin of appreciation for immigration control on the part of the Member States. ${ }^{115}$ Factors to be taken into account in this exercise are, amongst others, 'the extent to which family life is effectively ruptured, the extent of the ties in the Contracting State, whether there are insurmountable obstacles in the way of the family living in the country of origin of one or more of them and whether there are factors of immigration control (for example, a history of breaches of immigration law) or considerations of public order weighing in favour of exclusion'. ${ }^{116}$ Of particular significance are the timing and the circumstances of the family formation. When family life is created at a time when the immigration status of one of the persons involved is precarious, the removal of the non-national family member is incompatible with Article $8 \mathrm{ECHR}$ only in exceptional circumstances. In Darren Omoregie, for instance, the ECtHR concluded that the refusal of Norway to grant a residence right to a Nigerian national who was married with his Norwegian wife and with whom he had a child did not violate Article 8 ECHR precisely because their family relationship was established when the applicant stayed in Norway unlawfully. In the Court's view, both partners should have known from the start that their prospects of being able to settle as a couple in Norway were precarious' ${ }^{117}$ The child was, in the Court's words, 'still at an adaptable age at the time when the disputed

\footnotetext{
114) Arguably, any other solution could lead to allegations of an ultra vires application of EU law. See, on this point, Van Elsuwege, supra note 60, p. 322.

115) Thym, D., 'Respect for Private and Family Life under Article 8 ECHR in Immigration Cases: A Human Right to Regularise Illegal Stay?', 2008 ICLQ 57(1), pp. 87-112.

116) Application No. 265/07, Darren Omoregie and Others v. Norway, 31 July 2008, para. 57; Application No. 50435/99, Rodrigues da Silva/Hoogkamer v. the Netherlands, 31 January 2006, para 39; Application No. 27663/95, Ajayi and Others v. the United Kingdom 22 June 1999; Application No. 44328/98, Solomon v. the Netherlands, 5 September 2000.

117) Application No. 265/07, Darren Omoregie and Others v. Norway, 31 July 2008, para. 59.
} 
measures were decided and implemented' and therefore it did not find any insurmountable obstacles to develop family life in Nigeria. ${ }^{118}$ In light of this judgment, it may appear uncertain whether the Belgian treatment of Ruiz Zambrano could be regarded as a violation of Article 8 ECHR. ${ }^{119}$

However, in the comparable case of Rodrigues da Silva, the ECtHR found that the threatened removal of the Brazilian mother of a Dutch minor child violated Article $8 \mathrm{ECHR}$ and this notwithstanding the fact that she was residing unlawfully in the Netherlands at the time of her child's birth and no longer lived together with her Dutch partner. ${ }^{120}$ The Court took into account the child's interests and the observation that lawful residence in the Netherlands would have been possible during the period of the applicant's relationship with her Dutch partner. ${ }^{121}$ In the more recent Nunez v. Norway judgment, the ECtHR confirmed the importance of child interests in assessing the balance between the competing interests of the individual and of the community as a whole. ${ }^{122}$ In this case, a Dominican national arrived in Norway in 1996 as a tourist. After she was found guilty of theft, the Norwegian authorities deported her with a prohibition to reenter Norway for a period of two years. Four months later, she returned to Norway with a different passport and shortly afterwards she married a Norwegian national. After the couple divorced, Mrs. Nunez co-habited with a settled immigrant of Dominican origin in Norway. Together, they had two daughters. Despite the incontestable breach of Norwegian immigration law and the observation that Mrs. Nunez could not reasonably have entertained any expectation of being able to remain in the country ${ }^{123}$ - thus reflecting the Darren Omoregie situation - the ECtHR nevertheless concluded that it was in the children's interest that their mother stayed in Norway. ${ }^{124}$ As argued in the concurring opinion of Judge Jebens, this approach, which emphasises the priority to be given to the interests of the child in assessing a potential violation of Article $8 \mathrm{ECHR}$, inevitably reduces the States' margin of appreciation in such cases. ${ }^{125}$

Applied to the circumstances of the Ruiz Zambrano case, it may well be argued that the Belgian expulsion decision also violated Article $8 \mathrm{ECHR}$ and the fundamental right to family life as part of the general principles of EU law. The impact

\footnotetext{
118) Ibid. para. 66.

119) Hailbronner \& Thym, supra note 50, p. 1261.

120) Application No. 50435/99, Rodrigues da Silva/Hoogkamer v. the Netherlands, 31 January 2006.

121) She never applied for a residence permit due to unavailability of documents concerning her partner's income.

122) Application No. 55597/09, Nunez v. Norway, 28 June 2011.

123) Ibid., paras. 72-74.

124) Ibid., paras. 81-84.

125) Concurring Opinion of Judge Jebens to Application No. 55597/09, Nunez v. Norway, 28 June 2011. In their joint dissenting opinion to this case judges Mijovic and Gaetano confirmed and regretted this trend by arguing that this line of case law 'will send the wrong signal, namely that persons who are illegally in a country can somehow contrive to have their residence "legitimised" through the expedient of marriage and of having children'.
} 
of the envisaged deportation of Mr. Ruiz Zambrano on his children would be tremendous. They would no longer be able to live an independent life in Belgium, where they were born and raised. ${ }^{126}$ It seems, therefore, that the Darren Omoregie proviso does not apply in this case as a result of the children's interests and in line with the ECtHR conclusion in Nunez v. Norway. The explicit provision of Article 24 (2) of the Charter of Fundamental Rights that in all actions related to children, whether taken by public authorities or private institutions, the children's best interests must be a primary consideration', reinforces this interpretation. This all makes the CJEU's ignorance of the fundamental rights dimension even more surprising. However, the crucial question in Ruiz Zambrano was whether or not this situation fell within the scope of EU law. Without such a link, the fundamental rights protected by the EU simply do not apply. As it appeared that the granting of a work and residence permit to Mr. Ruiz Zambrano derives directly from the Treaty provisions on EU citizenship, a fundamental rights assessment was unnecessary to conclude the case.

In contrast to the Member State's discretionary power in the context of the ECHR, the rules on EU citizenship provide clear-cut rights for individuals that fall within its scope of application, ${ }^{127}$ without leaving much appraisal for the Member States. ${ }^{128}$ Moreover, Article 8 ECHR does not grant a right of entry or residence in order to be reunited with family members in a specific country. ${ }^{129}$ If it is possible for the family to live together elsewhere, it is likely that no interference with the right to respect for family life will be found ${ }^{130}$ - although notable examples to the contrary can also be provided. ${ }^{131}$ The situation is quite different under EU law, where residence in the territory of the Union plays a crucial role. In Metock, for instance, the Court clarified that 'the refusal of the host Member State to grant rights of entry and residence to the family members of a Union citizen is such as to discourage that citizen from moving to or residing in that Member State ${ }^{132}$ If migrant Union citizens would not be allowed to be accompanied by their third country family members in the host Member State, the

\footnotetext{
126) Opinion of AG Sharpston in Ruiz Zambrano, para. 63.

127) It is noteworthy that EU law works very differently in practice with regard to same-sex couples, de facto allowing the Member States to ignore each other's definitions of 'family'. See: Kochenov, D., 'On Options of Citizens and Moral Choices of States: Gays and European Federalism', 2009 Fordham. J. Int'l L. 33(1), pp. 156-206.

128) Case C-34/09, Ruiz Zambrano [2011] ECR I-0000, para. 45; Case C-578/08, Chakroun, [2010] ECR I-1839, para. 41

129) Application No 23218/94, Gülv. Switzerland, judgment of 19 February 1996, para. 38; Application No. 50435/99, Rodrigues da Silva/Hoogkamer v. the Netherlands, 31 January 2006, para. 39; Application No. 55597/09, Nunez v. Norway, 28 June 2011, para. 66.

130) E.g. Application No 21702/93, Ahmut v. the Netherlands, judgment of 28 November 1996, para. 71; Application 53102/99, Chandra and Others v. the Netherlands, decision of 13 May 2003; Application No. 265/07, Darren Omoregie and Others v. Norway, 31 July 2008, para. 66.

131) E.g. Application No 48321/99 Slivenko et al. v. Latvia, judgment of 9 October 2003; Application No. 60654/00 Sisojeva et al. v. Latvia, judgment of 15 January 2007.

132) Case C-127/08, Metock [2008] ECR I-6241, para. 64
} 
exercise of the free movement of persons would be seriously obstructed. Significantly, with regard to static Member State nationals the criterion is different and concerns the question whether or not a person's residence 'in the territory of the Union' is at stake. ${ }^{133}$

In other words, EU citizenship offers a different and often more extensive protection of family life than Article 8 ECHR. This may be regarded as a welcome development but, at the same time, it reinforces the feeling that issues of reverse discrimination are hard to accept in 'a Union under the rule of law, in which respect for fundamental rights must necessarily play an integral part'. ${ }^{134}$ The Court's silence on the human rights dimension on the right to family life is regrettable but understandable in light of the limits imposed on the application of the Charter of Fundamental Rights - which was moreover not legally binding at the time of the relevant facts - and the warning against judicial activism in the Lisbon judgment of the German Constitutional Court. ${ }^{135}$

\section{Concluding Remarks}

At the current stage of the European integration process, the right to family reunification is not a self-standing right under EU citizenship law. In the eyes of the $\mathrm{CJEU}$ its importance is reduced to a functional instrument in order to guarantee, on the one hand, the right to free movement of persons, as well as, on the other hand, the genuine enjoyment of EU citizens' other rights stemming from EU law. Paradoxically, this situation is different for legally resident third country nationals who can claim a direct right to family reunification in their resident Member State on the basis of Directive 2003/86. A majority of static Union residents, on the other hand, remains subject to the case by case approach of the ECtHR and the protection which is offered, if they are lucky, under national constitutional law.

The different options for family reunification depending upon whether a person manages to find a link with the scope of application of EU law and, in particular, the legal uncertainty about the exact limits of the Court's 'cross-border' and 'genuine enjoyment' tests reinforce the perception that reverse discrimination against a certain category of static Union citizens is fundamentally unfair. This conclusion is reinforced once the assumptions behind the national regulation responsible for reverse discrimination are in order. In this context, denying an EU dimension to the family reunification claims of static EU citizens against their

133) Case C-34/09, Ruiz Zambrano [2011] ECR I-0000, para. 44; Case C-434/09, McCarthy [2011] ECR I-0000, para. 50.

134) Opinion of AG Sharpston in Ruiz Zambrano, para. 3.

135) See, on this point, Van Elsuwege, supra note 60, p. 322. 
home Member States is becoming increasingly untenable. ${ }^{136}$ The discussion on the revision of Directive 2003/86, to be launched with a Commission Green Paper in November 2011, may therefore be a good opportunity to initiate legislative action in this field.

136) Costello, C., 'Metock: Free Movement and "Normal Family Life" in the Union', 2009 CMLRev. 46(2), pp. 587-622, 622. 